\title{
ВИЗНАЧЕННЯ СТУПЕНЯ НІКОТИНОВОЇ ЗАЛЕЖНОСТІ У ВІДВІДУВАЧІВ ПОЛІКЛІНІКИ ЗАЛІЩИЦЬКОЇ ЦЕНТРАЛЬНОЇ РАЙОННОЇ КОМУНАЛЬНОЇ JIKAPHI
}

\author{
X. С. Чабан, I. Я. Криницька, М. I. Марущак \\ Заліщищька центральна районна комунальна лікарня \\ ДВНЗ «Тернопільський державний медичний університет \\ імені І. Я. Горбачевського МОЗ України»
}

Визначено ступінь нікотинової залежності у відвідувачів, які проходили профілактичні огляди в поліклініці Заліщицької центральної районної комунальної лікарні. Звернено увагу на гендерні відмінності статусу курця у досліджуваній групі респондентів.

\section{THE DEGREE OF NICOTINE DEPENDENCE AMONG THE VISITORS IN THE CLINIC OF ZALISHCHYKY CENTRAL DISTRICT MUNICIPAL HOSPITAL}

\author{
H. S. Chaban, I. Ya. Krynytska, M. I. Marushchak \\ Zalishchyky Central District Municipal Hospital \\ I. Horbachevsky Ternopil State Medical University
}

\begin{abstract}
The degree of smoking addiction among the visitors who had preventive examinations in the clinic of Zalishchyky Central District Municipal Hospital has been studied. Attention is drawn to the gender differences in smoking status of the respondents of investigated group.
\end{abstract}

Вступ. Сучасна медико-демографічна ситуація в Україні характеризується тим, що країна вступила в якісно новий етап свого розвитку - депопуляцію. Уже 20 років річна чисельність померлих перевищує чисельність народжених. За 5 років (2006-2010) чисельність населення скоротилася на 1 млн 151 тис. осіб [5]. Така ситуація відбувається на тлі прогресуючого поширення тютюнокуріння, а також інших згубних шкідливих звичок [4].

За даними звіту ВООЗ про глобальну тютюнову епідемію за рівнем поширеності куріння серед дорослих (38,2 \%), Україна перебуває на шостому місці серед 45 країн Європейського регіону та на сьомому місці у світі. ІІї випереджають лише Греція, Науру, Росія, Австрія, Сербія, Боснія та Герцоговина [8].

Куріння є провідним фактором ризику таких хронічних неінфекційних захворювань, як ішемічна хвороба серця, артеріальна гіпертензія, атеросклеротична хвороба судин головного мозку, атеросклероз пе-

(ㄷ Х. С. Чабан, І. Я. Криницька, М. І. Марущак, 2017 риферичних судин, хронічна обструктивна хвороба легень, гастрити, гастродуоденіти, злоякісні новоутворення та інші $[1,2,6,9]$. Так, ризик передчасної смерті від ішемічної хвороби серця серед чоловіків, які курять у віці 40-59 років і жінок у віці 30-69 років в три рази перевищує аналогічний показник серед осіб, які не курять [3].

Дані захворювання не тільки погіршують якість життя, але і зумовлюють розвиток серйозних ускладнень, наприклад, інфаркту міокарда, інсульту головного мозку, тромбозу судин нижніх кінцівок, тяжкої дихальної недостатності. Дані стани спричиняють стійку втрату працездатності, а в деяких випадках закінчуються летально.

У літературних джерелах багато робіт присвячено дослідженню впливу куріння на організм. Однак ряд аспектів комплексної оцінки статусу курця осіб, які курять, залишений без належної уваги. Тому метою дослідження було визначення ступеня нікотинової залежності у відвідувачів, які проходили профілак- 
тичні огляди в поліклініці Заліщицької центральної районної комунальної лікарні.

Основна частина. У роботі проведено дослідження 104 відвідувачів, які проходили профілактичні огляди в поліклініці Заліщицької центральної районної комунальної лікарні, схильних до регулярного активного куріння.

Критеріями включення пацієнтів у групу спостереження були: регулярне активне куріння (від 1 сигарети щодня і частіше); вік від 18 до 60 років.

Критерії виключення пацієнтів з групи: вік менше 18 і більше 60 років; нерегулярне куріння (менше 1 сигарети на добу), куріння в минулому; тяжка серцева недостатність; хронічні захворювання внутрішніх органів у стадії загострення; системні захворювання сполучної тканини; злоякісні захворювання, відмова від участі в дослідженні.

Контрольна група була представлена 30 практично здоровими особами (12 жінок і 18 чоловіків) віком від 18 до 60 років. Середній вік серед обстежених чолові- чої статі становив $(35,4 \pm 11,5)$ року. Середній вік серед обстежених жіночої статі становив $(31,2 \pm 8,4)$ року.

Для характеристики статусу курця ми використали вік початку куріння, стаж куріння, його інтенсивність, індекс пачко/років, попередні спроби кинути курити, ступінь нікотинової залежності.

У цілому, ранній початок куріння (до 18 років) спостерігався у $45 \%$ обстежених. Середній вік початку куріння склав $(18,2 \pm 2,7)$ року. У групі обстежених чоловічої статі даний показник становив $(17,8 \pm 2,5)$ року, в групі жіночої статі - $(18,6 \pm 2,6)$ року.

Середній стаж куріння склав $(24,4 \pm 12,6)$ року. При цьому, в чоловіків стаж куріння виявився значно вищим і становив $(30,1 \pm 13,3)$ року, в той час, як у жінок цей показник дорівнював $(18,1 \pm 10,3)$ року.

Інтенсивність куріння, яка вимірюється в кількості сигарет, що викурюються за добу, в середньому дорівнювала $(16,0 \pm 4,9)$ сигарети. Серед чоловіків цей показник склав $(19,4 \pm 5,1)$ сигарети, серед жінок $(11,6 \pm 4,7)$ сигарети (табл. 1$)$.

таблиця 1. Показники статусу курця в групі дослідження

\begin{tabular}{|l|c|c|c|}
\hline \multicolumn{1}{|c|}{ Показник } & $\begin{array}{c}\text { Всього } \\
(\mathrm{n}=104)\end{array}$ & $\begin{array}{c}\text { Чоловіки } \\
(\mathrm{n}=60)\end{array}$ & $\begin{array}{c}\text { Жінки } \\
(\mathrm{n}=44)\end{array}$ \\
\hline Вік початку куріння, років & $18,2 \pm 2,7$ & $17,8 \pm 2,5$ & $18,6 \pm 2,6$ \\
\hline Стаж куріння, років & $24,4 \pm 12,6$ & $30,1 \pm 13,3$ & $18,1 \pm 10,3^{*}$ \\
\hline Інтенсивність куріння, сигарет на добу & $16,0 \pm 4,9$ & $19,4 \pm 5,1$ & $11,6 \pm 4,7$ \\
\hline Індекс пачко/років & $19,0 \pm 9,8$ & $27,5 \pm 12,1$ & $10,2 \pm 6,8^{*}$ \\
\hline
\end{tabular}

Примітка. * - різниця достовірна у порівнянні показників чоловіків та жінок $(p<0,05)$.

Розрахунок індексу пачко/років, що відображає сумарний вплив стажу куріння і його інтенсивності, показав, що в середньому цей показник склав $(19,0 \pm 9,8)$ пачко/років. Поряд із відмінностями за показниками стажу куріння і його інтенсивності, за цим параметром $\epsilon$ статистично значущі відмінності в групах чоловічої і жіночої статі, $(27,5 \pm 12,1)$ і $(10,2 \pm 6,8)$ пачко/років відповідно.
Всім пацієнтам було поставлено запитання про попередні спроби відмовитися від тютюнокуріння. Були отримані такі результати, 40,5 \% вже коли-небудь кидали курити, але через різні проміжки часу закурювали знову, 35,9 \% намагалися кинути курити, але не досягли бажаного результату, 23,6 \% ніколи не намагалися відмовитися від куріння (рис. 1).

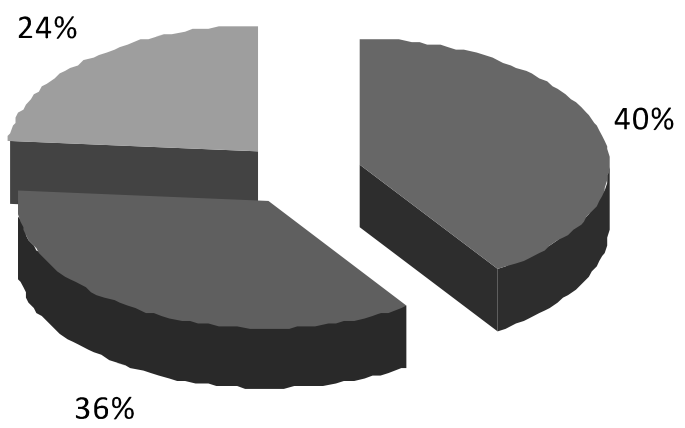

кидали курити, але закурювали знову

намагалися кинути курити

- ніколи не намагалися відмовитися від куріння

Puc. 1. Дані про попередні спроби кинути курити в обстеженій групі. 
Визначення ступеня нікотинової залежності проводилось за допомогою загальноприйнятого тесту шведського вченого Карла Фагерстрема, який заповнювався відвідувачами власноруч. Тест визначає зв'язок між індивідуальним балом і тяжкістю проявів абстинентного синдрому. Процедура тестування по- лягає в тому, що респондент повинен відповісти на шість запитань, кожна відповідь оцінюється певною кількістю балів (табл. 2).

При інтерпретації результатів враховується сумарний показник, при цьому виділяються п'ять діапазонів його значень (табл. 3).

таблиця 2. Тест Фагерстрема для визначення ступеня нікотинової залежності

\begin{tabular}{|c|c|c|}
\hline Запитання & Відповідь & Бали \\
\hline \multirow{4}{*}{$\begin{array}{l}\text { Як швидко, після того як прокинулись, } \\
\text { Ви викурюєте першу цигарку? }\end{array}$} & Протягом перших 5 хв & 3 \\
\hline & Протягом 6-30 хв & 2 \\
\hline & Протягом 30-60 хв & 1 \\
\hline & Через 1 год & 0 \\
\hline \multirow{2}{*}{$\begin{array}{l}\text { Чи складно для Вас утриматися від курін- } \\
\text { ня в місцях, де заборонено курити? }\end{array}$} & Так & 1 \\
\hline & $\mathrm{Hi}$ & 0 \\
\hline \multirow{2}{*}{$\begin{array}{l}\text { Від якої цигарки Ви не можете легко від- } \\
\text { мовитися? }\end{array}$} & Перша цигарка вранці & 1 \\
\hline & Всі решта & 0 \\
\hline \multirow[t]{4}{*}{ Скільки цигарок Ви викурюєте за день? } & 10 або менше & 0 \\
\hline & $11-20$ & 1 \\
\hline & $21-30$ & 2 \\
\hline & 31 і більше & 3 \\
\hline \multirow{2}{*}{$\begin{array}{l}\text { Коли Ви більше курите - вранці чи про- } \\
\text { тягом дня? }\end{array}$} & Вранці & 1 \\
\hline & Протягом дня & 0 \\
\hline \multirow{2}{*}{$\begin{array}{l}\text { Чи курите Ви, коли хворі і змушені пере- } \\
\text { бувати в ліжку цілий день? }\end{array}$} & Tак & 1 \\
\hline & $\mathrm{Hi}$ & 0 \\
\hline & Загалом & \\
\hline
\end{tabular}

таблиця 3. Інтерпретація результатів тесту Фагерстрема

\begin{tabular}{|l|l|}
\hline \multicolumn{1}{|c|}{ Кількість балів } & \multicolumn{1}{|c|}{ Результат } \\
\hline $0-2$ & Дуже слабка нікотинова залежність \\
\hline $3-4$ & Слабка нікотинова залежність \\
\hline 5 & Середня нікотинова залежність \\
\hline $6-7$ & Висока нікотинова залежність \\
\hline $8-10$ & Дуже висока нікотинова залежність \\
\hline
\end{tabular}

При визначенні ступеня нікотинової залежності було визначено, що середній рівень в групі дослідження становить $(5,57 \pm 1,74)$ бала, що відповідає рівню фізичної залежності від нікотину вище середнього. У групі жіночої статі цей показник склав $(4,9 \pm 1,78)$ бала, що можна інтерпретувати, як рівень залежності нижче середнього або середній. У групі чоловіків середній показник нікотинової залежності склав $(6,0 \pm 1,61)$ бала, що відповідає значенню середньої і високої залежності.

На рисунку 2 наведено розподіл респондентів за ступенями нікотинової залежності від дуже слабкої до дуже високої. 3 наведеного графіка видно, що серед чоловіків переважають особи із середньою, високою і дуже високою нікотиновою залежністю, 28,5, 35,0 і 24,8 \%, відповідно, і практично відсутні особи з дуже слабкою залежністю (1,6 \%). Серед жінок, навпаки, дуже мала кількість осіб має дуже високу залежність (3,2 \%), тоді як 15,0 \% - дуже слабкий ступінь нікотинової залежності.

Висновки. Статус курця відвідувачів поліклініки Заліщицької центральної районної комунальної лікарні характеризується початком куріння в чоловіківу середньому в $(17,8 \pm 2,5)$ року, в жінок у $(18,6 \pm 2,6)$ року, інтенсивністю куріння в середньому $(19,4 \pm 5,1)$ сигарети на добу в чоловіків, у жінок $(11,6 \pm 4,7)$ сигарети на добу. За ступенем куріння 41,1 \% жінок належать до легкого, 88,3 \% чоловіків до помірного і тяжкого куріння. Ніколи не намагалися відмовитися від куріння тільки 23,6 \% обстежуваних. Отримані дані про статус курця відвідувачів поліклініки рекомендується використовувати при плануванні й проведенні профілактичних заходів популяційного та індивідуального характеру. 


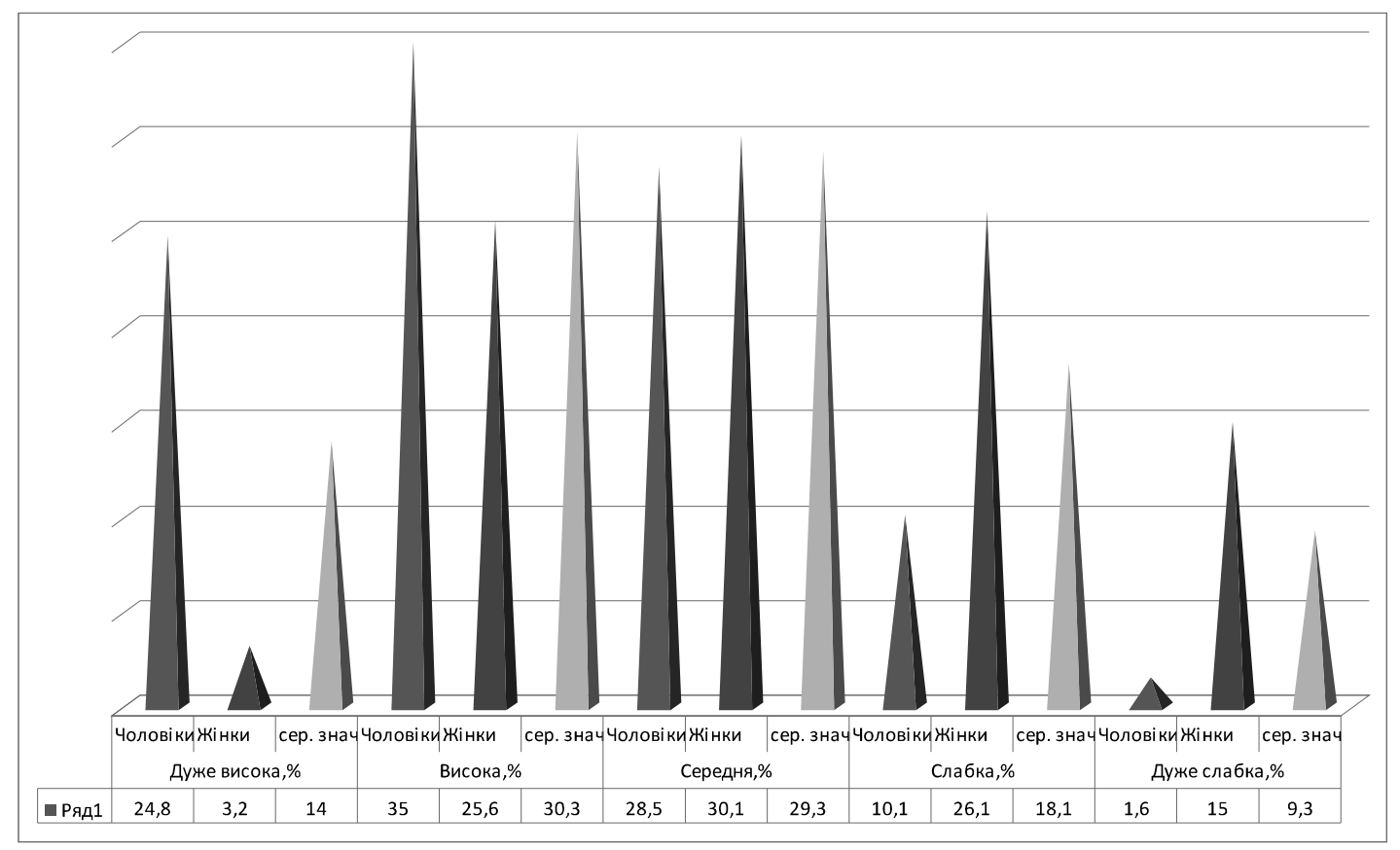

Puc. 2. Розподіл пацієнтів за ступенем нікотинової залежності.

\section{СПИСОК ЛІТЕРАТУРИ}

1. Архіпова Г. І. Вплив тютюнопаління на організм людини / Г. І. Архіпова, Ю. С. Макаренко // Вісник НАУ. 2012. - № 3. - С. 140-142.

2. Бабанов С. А. Роль табакокурения в развитии хронических неспецифических заболеваний легких (обзор литературы) / С. А. Бабанов // Здравоохранение Российской Федерации. - 2002. - № 1. - С. 53- 55.

3. Драпкина О. М. Курение и ассоциированные с ним проблемы в практике кардиолога / О.М.Драпкина // Артериальная гипертензия. - 2010. - Т. 16, № 2. С. 164-169.

4. Ещенко К. Н. Сердечно-сосудистая система и курение / К. Н. Ещенко, А. В. Жадан, Н. Ф. Шустваль // Ліки України. 2013. - Вип. 4. - С. 12-17.

5. Контроль над тютюном в Україні. Другий Національний звіт. - К. : МОЗ України, ДУ «Український інститут стратегічних досліджень МОЗ України», 2014. - 128 с.
6. Курение и сердечно-сосудистая система / Н. А. Барбараш, Л. С. Барбараш, О. Л. Барбараш [и др.] // Consilium medicum. - 2013.- № 1. - С. 44- 47.

7. Про затвердження «Переліку шкідливих для здоров'я людини речовин, що входять до складу тютюнових виробів, виділяються з тютюновим димом під час їх куріння» : наказ МОЗ України від 25.02.2011 р. № 105.

8. Оцінка динаміки поширеності тютюнокуріння в Україні / К. С. Красовський, Т. І. Андреєва, А. А. Григоренко, Н. А. Бутильська // Вісник соціальної гігієни та організації охорони здоров'я України. - 2009. - № 2. - С. 91-99.

9. Хронічне обструктивне захворювання легень: етіологія, патогенез, класифікація, діагностика, терапія (проект національної угоди) / Ю.І. Фещенко, Л. О. Яшина, О. Я. Дзюблик [та ін.] // Український пульмонологічний журнал. - 2013. - № 3. - С. 7-12. 